Для цитирования: Цыганов М.М., Ибрагимова М.К., Певзнер А.М., Литвяков Н.В. Потеря гетерозиготности локусов генов BRCA1 и BRCA2 в опухоли молочной железы. Современный взгляд на проблему. Сибирский онкологический журнал. 2020; 19(3): 97-101. - doi: 10.21294/1814-4861-2020-19-3-97-101.

For citation: Tsyganov M.M., Ibragimova M.K., Pevzner A.M., Litviakov N.V. Loss of heterozygosity in the BRCA1 and BRCA2 locus in breast cancer. Siberian Journal of Oncology. 2020; 19(3): 97-101 - doi: 10.21294/1814-4861-2020-19-3-97-101.

\title{
LOSS OF HETEROZYGOSITY IN THE BRCA1 AND BRCA2 LOCUS IN BREAST CANCER
}

\author{
M.M. Tsyganov, M.K. Ibragimova, A.M. Pevzner, N.V. Litviakov \\ Cancer Research Institute, Tomsk National Research Medical Center, \\ Russian Academy of Sciences, Tomsk, Russia \\ 5, Kooperativny Street, 634050, Tomsk, Russia. E-mail: TsyganovMM@yandex.ru
}

\section{Abstract}

One of the factors of variability of malignant neoplasms is the loss of heterozygosity (LOH). The biological meaning of $\mathrm{LOH}$, in relation to carcinogenesis, is associated with the inactivation of heterozygous loci of pathogenetically significant genes. Thus, the aim of this work was to study BRCA1/2 LOH in breast tumors. Material and Methods. The study included 122 patients with stage IIAIIIC breast cancer. DNA was isolated from 122 biopsy samples of tumor tissue using the QIAamp DNA mini Kit (Qiagen, Germany). To assess the status of LOH, microarray analysis was performed on high-density DNA chips from Affymetrix CytoScanTM HD Array. To process the results of microchipping, we used the Chromosome Analysis Suite 3.3 program (Affymetrix, USA). Results. The loss of heterozygosity in the BRCA1 gene was found to be associated with response to NAC. It was shown that in 59 patients $\mathrm{LOH}$ in the BRCA1gene was associated with an objective response to treatment $(p=0.005)$. The presence of $\mathrm{LOH}$ in the studied genes was associated with a favorable prognosis. The 5-year non-metastatic survival rates were $75 \%$ and $100 \%$ in patients with $\mathrm{LOH}$ in the $B R C A 1$ and $B R C A 2$ genes, respectively (log-rank test: $p=0.003$ and $p=0.05$, respectively). Conclusion. The phenomenon of $\mathrm{LOH}$ in the BRCA1/2 genes was shown to be associated with response to NACT. BRCA1/2. Further studies are needed to evaluate the frequency of $B R C A 1 / 2 \mathrm{LOH}$ after NAC for choosing and changing treatment tactics.

Key words: breast cancer, BRCA1 and BRCA2 mutation in the tumor, loss of heterozygosity, microarray analysis, personalized medicine.

\section{ПОТЕРЯ ГЕТЕРОЗИГОТНОСТИ ЛОКУСОВ ГЕНОВ ВRСА1 И BRCA2 В ОПУХОЛИ МОЛОЧНОЙ ЖЕЛЕЗЫ}

\author{
М.М. Цыганов, М.К. Ибрагимова, А.М. Певзнер, Н.В. Литвяков \\ Научно-исследовательский институт онкологии, Томский национальный исследовательский \\ медицинский центр Российской академии наук, г. Томск, Россия \\ Россия, 634009, г. Томск, пер. Кооперативный, 5. E-mail: TsyganovMM@yandex.ru
}

\section{Аннотация}

Одним из факторов вариабельности злокачественных новообразований является потеря гетерозиготности (LOH - loss of heterozygosity). Предполагается, что биологический смысл LOH применительно к канцерогенезу связан с инактивацией гетерозиготных локусов патогенетически значимых генов. Целью исследования явилось исследование потери гетерозиготности генов $B R C A 1 / 2$ в опухоли молочной железы. Материал и методы. В исследование были включены 122 больных раком молочной железы IIA-IIIC стадии. ДНК выделяли из 122 биопсийных образцов опухолевой ткани с помощью набора QIAamp DNA mini Kit (Qiagen, Germany). Для оценки статуса LOH проведен микроматричный анализ на ДНК-чипах высокой плотности фрирмы Affymetrix CytoScanTM HD Array. Для обработки ре- 
зультатов микрочипирования использовали программу «Chromosome Analysis Suite 3.3» (Affymetrix, USA). Результаты. В результате проведенного исследования было установлено, что наличие потери гетерозиготности в гене BRCA1 сопряжено с ответом на неоадъювантную химиотерапию. Показано, что у 59 больных наличие LOH в гене BRCA1 сопряжено с объективным ответом на лечение $(p=0,005)$. Наличие потери гетерозиготности в изучаемых генах сопряжено с благоприятным прогнозом. Показатель 5-летней безметастатической выживаемости у пациентов с потерей гетерозиготности для гена BRCA1 составляет 75 \% (log-rank test p=0,003), для гена BRCA2 все пациенты имели 100 \% безметастатическую выживаемость, log-rank test $p=0,05$. Заключение. Показано, что потеря гетерозиготности в генах $B R C A 1 / 2$ связана с эффективностью неоадъювантной химиотерапии, а также является независимым прогностическим фрактором. С учетом полученных результатов можно предположить, что инактивация $B R C A 1 / 2$ должна коррелировать с чувствительностью к терапии на основе платины, что, несомненно, делает дальнейшее изучение данного вопроса актуальным.

Ключевые слова: рак молочной железы, мутация BRCA1 и $B R C A 2$ в опухоли, потеря

гетерозиготности, микроматричный анализ, персонализированная медицина.

\section{Introduction}

Currently, the phenomenon of «loss of heterozygosity» ( $\mathrm{LOH}$ - loss of heterozygosity) is very often observed in tumor tissue. This phenomenon represents a loss of heterozygous alleles in a certain part of the genome, which may be due to either deletion of the chromosome portion in one of the copies of the chromosomes or the whole chromosome, or the replacement of one of the parent copies in the process of gene conversion - copies are neutral LOH [1]. The loss of heterozygosity is associated with the mechanism of tumor development, following the two-hit model of carcinogenesis described by A. Knudson in 1971 [2]. According to this view, the first stage of tumor development is a point mutation or a change in gene expression, but by itself it does not lead to disease. And only in the case of the next stage, in the form of the loss of the wild-type allele (directly the loss of heterozygosity), the process of cell malignancy occurs. In this case, the loss of the allele makes it possible to manifest fatal recessive mutations, and in addition, activation of oncogenes and inactivation of tumor suppressor genes can occur, which leads to uncontrolled cell growth and metastasis $[3,4]$.

Currently, the phenomenon of «loss of heterozygosity» has been well studied and shown for many genes in various locations of the tumor process. It is assumed that the biological meaning of LOH, as applied to carcinogenesis, is associated with the inactivation of heterozygous loci of pathogenetically significant genes [5-8]. We studied two regions of the long arm of chromosomes 13 and 17 (13q13.1 (BRCA2) and $17 \mathrm{q} 21.31$ (BRCA1), respectively) using the microarray analysis of $\mathrm{LOH}$ sites.

\section{Material and Methods}

The study included 122 patients aged 25-68 years $(53.43 \pm 0.78$ (Mean \pm SE)) with morphologically verified stage IIA-IIIB breast cancer (BC) (Table 1). All patients received 4-6 courses of neoadjuvant chemotherapy (NAC) with the FAC (fluorouracil, doxorubicin, cyclophosphamide), CAX (cyclophosphamide, doxorubicin, xeloda), CP (cyclophosphamide, cisplatin) regimens or monotherapy with taxotere. The patients underwent surgery 3-5 weeks after NAC. Then, they received adjuvant chemotherapy, radiation therapy and/or hormonal treatment as indicated. The study was carried out in accordance with the Helsinki Declaration of 1964 (amended in 1975 and 1983), and permission was received from the local ethics committee of the Oncology Research Institute of Tomsk Scientific Research Center (protocol No. 1, dated January 14, 2013). All patients signed informed consent. Tumor samples $\left(\sim 10 \mathrm{~mm}^{3}\right)$ were taken before the start of the treatment under the ultrasound control. Tumor samples were placed in an RNAlater solution (Ambion, USA) and stored at $-80^{\circ} \mathrm{C}$ (after 24-hour incubation at $+4{ }^{\circ} \mathrm{C}$ ) for further isolation of RNA and DNA.

DNA was isolated from 122 biopsy samples of tumor tissue using the QIAamp DNA mini Kit (Qiagen, Germany). DNA concentration and purity of isolation were evaluated on a Qubit 3.0 fluorimeter (Thermo Scientific, USA) using the Qubit DNA BR Assay Kit, $(50$ to $250 \mathrm{ng} / \mu \mathrm{l})$. DNA integrity was assessed by capillary electrophoresis on a TapeStation 2200 instrument using the Agilent Genomic DNA ScreenTape System Quick Guide (Agilent Technologies, USA)., DNA fragments had a mass of more than $48 \mathrm{kbp}$.

Microarray analysis was performed on high density microarrays (DNA chips) of Affymetrix (USA) CytoScanTM HD Array, which contained 2 million 670 thousand markers -1 million 900 thousand nonpolymorphic markers for the analysis of copy number aberrations (CNA) and more than 750 thousand single nucleotide polymorphisms. The presence of polymorphic markers on the microarray allows the areas with LOh to be identified. Sample preparation, hybridization, and scanning procedures were performed in accordance with the manufacturer's protocol on an Affymetrix GeneChip ${ }^{\circledR}$ Scanner 30007 G system (Affymetrix, USA). To process the microchip results, we used the Chromosome Analysis Suite 4.3 (Affymetrix, USA) program, which was developed specifically for analyzing the results of chipping on a CytoScanTM HD Array matrix.

Statistical data processing was performed using the STATISTICA 8.0 application software package (StatSoft Inc., USA). Comparison of frequencies 


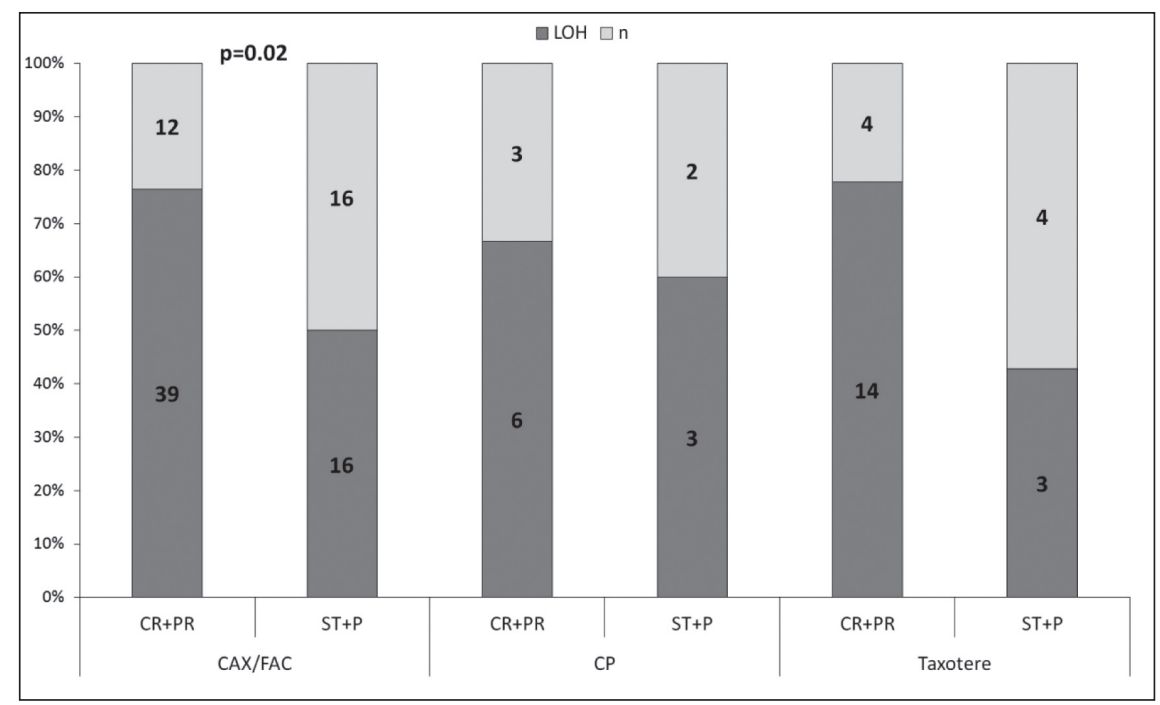

Рис. 1. Частота потери гетерозиготности гена BRCA1 в опухоли молочной железы в зависимости от неоадъювантной химиотерапии

Fig. 1. The frequency of loss of heterozygosity of $B R C A 1$ gene in breast tumor in relation to neoadjuvant chemotherapy

according to qualitative data was analyzed using the two-sided Fisher test (http://vassarstats.net/odds2x2. $\mathrm{html})$. Differences between the study groups were considered statistically significant at a significance level of $p<0.05$. For the analysis of non-metastatic survival, survival curves were constructed using the Kaplan-Meier method. To compare differences in survival between the treatment groups, the log-rank test was used.

\section{Results}

The LOH frequency at the $17 \mathrm{q} 21.31$ and $13 \mathrm{q} 13.1$ loci with the BRCA1/2 genes was $63.9 \%(78 / 122)$ and $11.5 \%(14 / 122)$, respectively. A statistically significant difference only in response to neoadjuvant chemotherapy was found. It was shown that in $73 \%$ of cases (59/81), the presence of $\mathrm{LOH}$ in the BRCA1 gene in tumor tissue before treatment was associated with an objective response to neoadjuvant chemotherapy (Fisher's exact test, $\mathrm{p}=0.005$ ), (table 2 ). The objective response to anthracycline-containing NAC regimens (FAC and CAX) was observed in $76 \%(39 / 51)$ patients with $\mathrm{LOH}$ in BRCA1 gene, while stabilization and disease progression were found in $50 \%(16 / 32)$ patients (Fisher's exact test, $\mathrm{p}=0.02$ ), (fig. 1). In patients treated with other chemotherapy regimens, no statistically significant differences were found due to a small number of samples.

Survival curves were estimated using the KaplanMeier method. The presence of $\mathrm{LOH}$ in the $B R C A 1 / 2$ genes in tumor tissue was shown to have a prognostic significance. The 5-year metastatic-free survival rate in patients with $\mathrm{LOH}$ in the BRCA1 gene was $75 \%$ compared to $60 \%$ in patients with normal BRCA1 gene (fig. 2A). The differences were statistically significant (the log-rank test: $\mathrm{p}=0.003$ ). In patients with $\mathrm{LOH}$ in the $B R C A 2$ gene, the 5-year metastatic-free survival was $100 \%$ (log-rank test: $\mathrm{p}=0.05$ ) (fig. $2 \mathrm{~B}$ ). However, no significant difference in the main clinical and morphological parameters between patients with $\mathrm{LOH}$ and patients with normal BRCA1/2 gene were found (table 2). Moreover, BRCA1/2 LOH was revealed to be an independent prognostic factor.

Thus, it was shown that the presence of $B R C A 1 / 2$ $\mathrm{LOH}$ in breast tumor tissue was associated with response to NAC and favorable outcome. Patients with

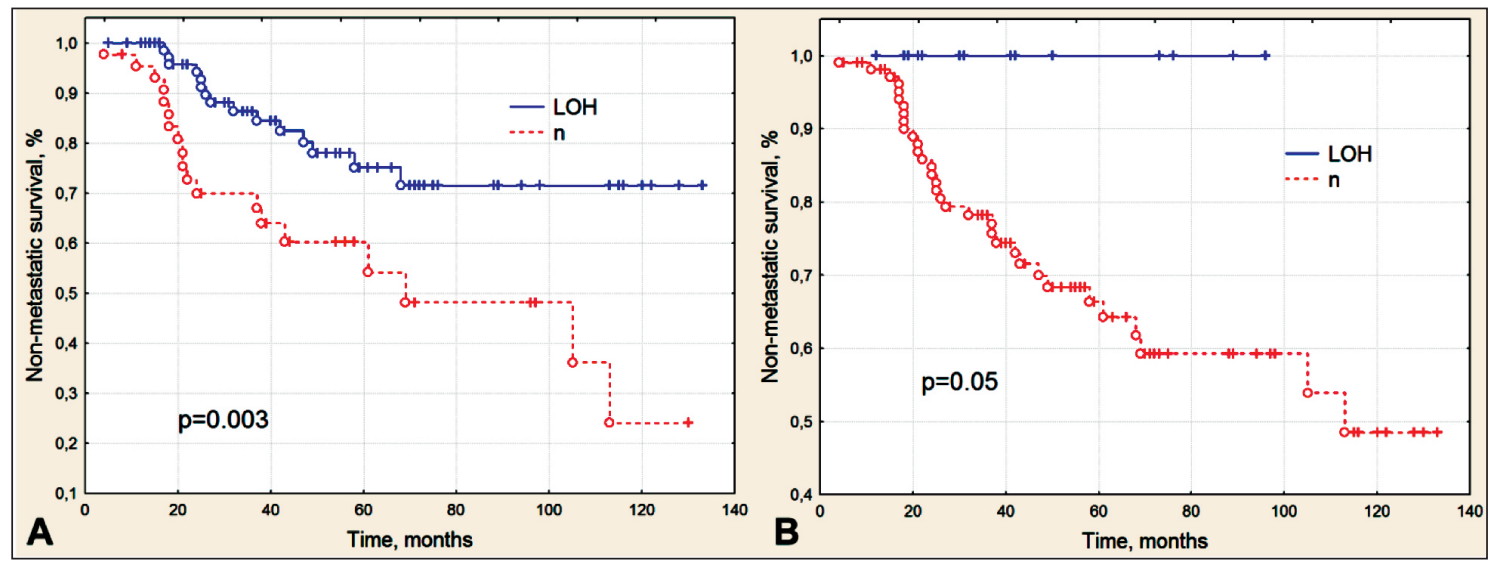

Рис. 2. Безметастатическая выживаемость больных раком молочной железы в зависимости от наличия сайтов потери гетерозиготности генов BRCA1 (A) и BRCA2 (B) в опухолевой ткани

Fig. 2. Non-metastatic survival of patients with breast cancer in relation to the loss of heterozygosity of $B R C A 1(A)$ and $B R C A 2(B)$ genes in tumor tissue 
the presence of $\mathrm{LOH}$ in the $B R C A 1$ gene had higher rates of objective response to treatment. Patients with $B R C A 1$ or/and $B R C A 2 \mathrm{LOH}$ had higher non-metastatic survival rates than patients with normal locus of these genes. The assessment of $\mathrm{LOH}$ in tumor tissue can be used as an additional criterion for personalizing neoadjuvant and adjuvant chemotherapy.

\section{Discussion}

Two years after the discovery of the BRCAl gene, in 1996 Beckmann M.W. et al. showed the possible clinical role of heterozygosity loss in the BRCA1 and $B R C A 2$ genes in sporadic breast cancer [9]. The frequency of $\mathrm{LOH}$ in the tumor was found to be $32-42 \%$ compared to $64 \%$ in our study. Moreover, the presence of this phenomenon in the BRCA1 gene was associated with the size of the tumor $(\mathrm{p}=0.02)$, and in the $B R C A 2$ gene with the stage of the disease $(\mathrm{p}=0.05)$. In addition, it was found that $\mathrm{LOH}$ was not associated with prognosis of the disease [9]. Such discrepancies may be associated with a low methodological level of $\mathrm{LOH}$ determination using minisatellite loci and PCR. The CytoScan HD Array microarray is a more reliable and sensitive tool for detecting all types of LOH. K.N. Maxwell et al. (2017) reported that in patients with ovarian cancer, the LOH frequency was only $10 \%$ in the BRCA1 gene and $46 \%$ in BRCA2. The normal $B R C A 1 / 2$ gene loci was associated with decreased survival rates (log-rank test $\mathrm{p}=0.01$ ) [10]. Other authors have also shown that the presence of $B R C A 1 \mathrm{LOH}$ in ovarian cancer patients is associated with a good response to neoadjuvant chemotherapy with platinum-containing drugs [11]. BRCAl/2 genes

\section{ЛИТЕРАTУPA/REFERENCES}

1. Ryland G.L., Doyle M.A., Goode D., Boyle S.E., Choong D.Y., Rowley S.M., Li J., Bowtell D.D., Tothill R.W., Campbell I.G. Loss of heterozygosity: what is it good for? BMC Med Genomics. 2015; 8: 45. doi: 10.1186/s12920-015-0123-z.

2. Knudson A.G. Mutation and cancer: statistical study of retinoblastoma. Proceedings of the National Academy of Sciences. 1971; 68(4): $820-823$

3. Chen Y., Chen C. DNA copy number variation and loss of heterozygosity in relation to recurrence of and survival from head and neck squamous cell carcinoma: a review. Head Neck. 2008; 30(10): 1361-83. doi: $10.1002 /$ hed.20861.

4. Silva J.M. Silva J., Sanchez A. Garcia J.M. Dominguez G. Provencio M., Sanfrutos L., Jareño E., Colas A., España P., Bonilla F. Tumor DNA in plasma at diagnosis of breast cancer patients is a valuable predictor of disease-free survival. Clinical Cancer Research, 2002; 8(12): 3761-3766.

5. Okudela K., Tateishi Y., Umeda S., Mitsui H., Suzuki T., Saito Y., Woo T. Tajiri M., Masuda M. Miyagi Y., Ohashi K. Allelic Imbalance in the miR-31 Host Gene Locus in Lung Cancer-Its Potential Role in Carcinogenesis. PLoS One. 2014 Jun 30; 9(6): e100581. doi: 10.1371/ journal.pone. 0100581

6. Fleming J.L., Dworkin A.M., Allain D.C., Fernandez S., Wei L., Peters S.B., Iwenofu O.H., Ridd K., Bastian B.C., Toland A.E. Allele specific imbalance mapping identifies HDAC9 as a candidate gene for cutaneous squamous cell carcinoma. Int J Cancer. 2014 Jan 1; 134(1): 244-8. doi: 10.1002/ijc.28339.

7. Shikeeva A., Kekeeva T., Zavalishina L., Andreeva I., Frank G. Allelic imbalance in patients with non-small cell lung cancer. Arkh Patol. 2013; 75(2): 3-8.

8. Saito M., Okamoto A., Kohno T., Takakura S., Shinozaki H., Isonishi S., Yasuhara T., Yoshimura T., Ohtake Y., Ochiai K., Yokota J., Tanaka T. Allelic imbalance and mutations of the PTEN gene in ovarian cancer. Int J Cancer. 2000; 85(2): 160-165. play an important role in DNA repair through homologous recombination, and the abnormalities in these genes lead to a homologous recombination deficiency (HRD). This is fully reflected in the response to chemotherapy in patients with breast cancer [12-14]. Thus, LOH can be a clinically useful biomarker for planning treatment not only for breast cancer, but for other cancer locations [15].

\section{Conclusion}

The $\mathrm{LOH}$ phenomenon in the $B R C A 1 / 2$ genes was shown to be associated with response to NAC and disease outcome. Patients with $B R C A 1$ or/and $B R C A 2$ $\mathrm{LOH}$ had higher non-metastatic survival rates than patients with normal locus of these genes. It can be theoretically assumed that the $B R C A 1 / 2$ inactivation correlates with sensitivity to platinum-based therapy. Further studies are needed to evaluate the frequency of $B R C A 1 / 2 \mathrm{LOH}$ after NAC for choosing and changing treatment tactics.

\section{Compliance with ethical principles}

The study was carried out with statements of compliance with ethical standards developed in accordance with the Helsinki Declaration of the World Medical Association «Ethical Principles for Conducting Scientific Medical Research with Human Participation» as amended in 2000 and the «Rules of Clinical Practice in the Russian Federation» approved by the Order of the Ministry of Health of the Russian Federation of June 19, 2003 No. 266. Informed consent was obtained from individuals who participated in the study.

9. Beckmann M.W., Picard F., An H.X., van Roeyen C.R., Dominik S.I., Mosny D.S., Schnürch H.G., Bender H.G., Niederacher D. Clinical impact of detection of loss of heterozygosity of BRCA1 and BRCA2 markers in sporadic breast cancer. Br J Cancer. 1996 May; 73(10): 1220-6.

10. Maxwell K.N., Wubbenhorst B., Wenz B.M., De Sloover D., Pluta J., Emery L., Barrett A., Kraya A.A., Anastopoulos I.N., Yu S., Jiang Y., Chen H., Zhang N.R., Hackman N., D'Andrea K., Daber R., MorrissetteJ.J.D., Mitra N., Feldman M., Domchek S.M., Nathanson K.L. BRCA locus-specific loss of heterozygosity in germline BRCA1 and BRCA2 carriers. Nat Commun. 2017 Aug 22; 8(1): 319. doi: 10.1038/s41467-017-00388-9.

11. Sokolenko A., Savanevich A., Stepuro T., Shulga A., Berlev I., Imyanitov E., Petrov N. Loss of heterozygosity at the BRCA1 locus as a marker of sen-sitivity for adjuvant chemotherapy in hereditary ovarian cancer. Biological Markers in Fundamental and Clinical Medicine. 2017; 1(3): 29-31.

12. Telli M.L., Hellyer J., Audeh W., Jensen K.C., Bose S., Timms K.M., Gutin A., Abkevich V., Peterson R.N., Neff C., Hughes E., Sangale Z., Jones J., Hartman A.R., Chang P.J., Vinayak S., Wenstrup R., Ford J.M. Homologous recombination deficiency (HRD) status predicts response to standard neoadjuvant chemotherapy in patients with triple-negative or BRCA1/2 mutation-associated breast cancer. Breast Cancer Res Treat. 2018 Apr; 168(3): 625-630. doi: 10.1007/s10549-017-4624-7.

13. Pennington K.P., Walsh T., Harrell M.I., Lee M.K., Pennil C.C., Rendi M.H., Thornton A., Norquist B.M., Casadei S., Nord A.S., Agnew K.J., Pritchard C.C., Scroggins S., Garcia R.L., King M.C., Swisher E.M. Germline and somatic mutations in homologous recombination genes predict platinum response and survival in ovarian, fallopian tube, and peritoneal carcinomas. Clin Cancer Res. 2014 Feb 1; 20(3): 764-75. doi: 10.1158/1078-0432.CCR-13-2287.

14. Литвяков Н.В., Чердыниева Н.В., Цьганов М.М., Денисов Е.В., Мерзлякова М.К., Гарбуков Е.Ю., Вторушин С.В., Завьялова М.В., Слонимская E.M. Ассоциация генетического полиморфизма с изменением экспрессии генов множественной лекарственной устойчивости в опухоли молочной железы в процессе неоадъюантной химиоте- 
рапии. Медицинская генетика. 2011; 10(10): 37-43. [Litviakov N.V., Cherdyntseva N.V., Tsyganov M.M., Denisov E.V., Merzliakova M.K., Garbukov E.Yu., Vtorushin S.V., Zavjalova M.V., Slonimskaya E.M. Influence of gene polymorphism on the expression of the multidrug resistance genes in breast tumor during neoadjuvant chemotherapy. Medical Genetics. 2011; 10(10): 37-43. (in Russian)].
15. Sakr S., Abdulfatah E., Loehr A., Simmons A., Morris R., AliFehmi R. Prognostic impact of loss of heterozygosity in uterine serous carcinoma. Gynecol Oncol. 2018; 149(1): 72.

Поступила/Received 15.08.2019 Принята в печать/Accepted 23.09.2019

\section{СВЕДЕНИЯ ОБ АВТОРАХ}

Цыганов Матвей Михайлович, кандидат биологических наук, старший научный сотрудник лаборатории онковирусологии, Научно-исследовательский институт онкологии, Томский национальный исследовательский медицинский центр Российской академии наук (г. Томск, Россия). E-mail: TsyganovMM@yandex.ru. SPIN-код: 1253-0240. Researcher ID (WOS): A-7212-2014. Author ID (Scopus): 55366377400. ORCID: 0000-0001-7419-4512.

Ибрагимова Марина Константиновна, младший научный сотрудник лаборатории онковирусологии, Научно-исследовательский институт онкологии, Томский национальный исследовательский медицинский центр Российской академии наук (г. Томск, Россия). SPIN-код: 2340-1628. Researcher ID (WOS): C-8609-2012. Author ID (Scopus): 57130579200. ORCID: 0000-0001-8815-2786.

Певзнер Алина Михайловна, лаборант-исследователь лаборатории онковирусологии, Научно-исследовательский институт онкологии, Томский национальный исследовательский медицинский центр Российской академии наук (г. Томск, Россия). SPINкод: 3847-3522, ORCID: 0000-0002-9657-9058.

Литвяков Николай Васильевич, доктор биологических наук, заведующий лабораторией онковирусологии, Научноисследовательский институт онкологии, Томский национальный исследовательский медицинский центр Российской академии наук (г. Томск, Россия). SPIN-код: 2546-0181. Researcher ID (WOS): C-3263-2012. Author ID (Scopus): 6506850698. ORCID: 0000-0002-0714-8927.

\section{ВКЛАД АВТОРОВ}

Цыганов Матвей Михайлович: разработка концепции научной работы, статистическая обработка.

Ибрагимова Марина Константиновна: анализ научной работы.

Певзнер Алина Михайловна: анализ научной работы, методология.

Литвяков Николай Васильевич: критический пересмотр с внесением ценного интеллектуального содержания.

\section{Финансирование}

Работа поддержана грантом РНФ № 19-75-00027 «Исследование соматического статуса гена BRCA1 в опухоли молочной железы для персонализированного назначения лечения».

Конфликт интересов

Авторы объявляют, что у них нет конфликта интересов.

\section{ABOUT THE AUTHORS}

Matvey M. Tsyganov, PhD, Researcher, Laboratory Oncovirology, Cancer Research Institute, Tomsk National Research Medical Center, Russian Academy of Sciences (Tomsk, Russia). E-mail: TsyganovMM@yandex.ru. Researcher ID (WOS): A-7212-2014. Author ID (Scopus): 55366377400. ORCID: 0000-0001-7419-4512.

Marina K. Ibragimova, Junior Researcher, Laboratory Oncovirology, Cancer Research Institute, Tomsk National Research Medical Center, Russian Academy of Sciences (Tomsk, Russia). E-mail: imk1805@yandex.ru. Researcher ID (WOS): C-8609-2012. Author ID (Scopus): 57130579200. ORCID: 0000-0001-8815-2786.

Alina M. Pevzner, Laboratory Assistant Researcher, Laboratory Oncovirology, Cancer Research Institute, Tomsk National Research Medical Center, Russian Academy of Sciences (Tomsk, Russia). ORCID: 0000-0002-9657-9058

Nikolay V. Litviakov, DSc, Head of the Laboratory Oncovirology, Cancer Research Institute, Tomsk National Research Medical Center, Russian Academy of Sciences (Tomsk, Russia). Researcher ID (WOS): C-3263-2012. Author ID (Scopus): 6506850698. ORCID: 0000-0002-0714-8927.

\section{AUTHOR CONTRIBUTION}

Matvey M. Tsyganov: study conception, statistical data analysis.

Marina K. Ibragimova: analysis of the study results.

Alina M. Pevzner: analysis of the study results, methodology.

Nikolay V. Litviakov: critical revision for the important intellectual content.

\section{Funding}

This study was supported by the Russian Science Foundation grant No. 19-75-00027 «Study of the somatic status of the BRCAl gene in a breast tumor for personalized treatment purposes».

\section{Conflict of interest}

The authors declare that they have no conflict of interest. 